\title{
Chemopreventive Potential of In Vitro Fermented Raw and Roasted Hazelnuts in LT97 Colon Adenoma Cells
}

\author{
MICHAEL GLEI ${ }^{1,2}$, SONJA FISCHER ${ }^{1}$, JULIA LAMBERTY ${ }^{1}$, DIANA LUDWIG ${ }^{1}$, \\ STEFAN LORKOWSKI ${ }^{2,3}$ and WIEBKE SCHLÖRMANN ${ }^{1,2}$ \\ ${ }^{1}$ Friedrich Schiller University Jena, Institute of Nutrition, Department of Nutritional Toxicology, Jena, Germany; \\ ${ }^{2}$ Competence Cluster for Nutrition and Cardiovascular Health (nutriCARD), Halle-Jena-Leipzig, Germany; \\ ${ }^{3}$ Friedrich Schiller University Jena, Institute of Nutrition, \\ Department of Nutritional Biochemistry and Physiology, Jena, Germany
}

\begin{abstract}
Background/Aim: Due to their unique composition of health-promoting compounds, the consumption of hazelnuts may contribute to the prevention of colon cancer. Materials and Methods: Since hazelnuts are often consumed roasted, the impact of different roasting conditions $\left(R C 1=140.6^{\circ} \mathrm{C} / 25 \mathrm{~min}, R C 2=155.1^{\circ} \mathrm{C} / 20 \mathrm{~min}\right.$ and $R C 3=180.4^{\circ} \mathrm{C} / 21 \mathrm{~min}$ ) on chemopreventive effects of in vitro fermented hazelnuts was analyzed in LT97 colon adenoma cells. Results: FS (2.5\%) of raw and roasted hazelnuts reduced $\mathrm{H}_{2} \mathrm{O}_{2}$-induced DNA damage while 5\% $\mathrm{FS}$ significantly induced gene expression of SOD2 (3.0-fold) and GSTP1 (2.1-fold). GPXI mRNA levels were significantly decreased (0.6-fold) by FS (2.5\%). The growth of LT97 cells was significantly reduced by hazelnut FS in a time- and dose-dependent manner. Hazelnut FS (5\%) increased the numbers of early apoptotic cells $(9.6 \%$ on average) and caspase-3 activities (6.4-fold on average). Conclusion: These results indicate a chemopreventive potential of in vitro fermented hazelnuts which is largely unaffected by the roasting process.
\end{abstract}

Chronic, non-communicable diseases like cardiovascular diseases, cancer or diabetes are the major causes of death worldwide (1). These diseases are heavily influenced by lifestyle factors and nutrition. Especially nuts have the potential to positively influence the risk for these diseases due to their unique composition of health-promoting nutrients such as minerals, vitamins, phytochemicals and unsaturated fatty acids $(2,3)$. Results from recent studies

Correspondence to: Wiebke Schlörmann, Friedrich Schiller University Jena, Institute of Nutrition, Department of Nutritional Toxicology, Dornburger Straße 24, 07743 Jena, Germany. Tel: +49 3641949694, Fax: +49 3641949672, e-mail: wiebke.schloermann@uni-jena.de

Key Words: Apoptosis, colon cancer, dietary fiber, hazelnuts. indicate that the consumption of nuts is associated with lower risks regarding cardiovascular diseases and diabetes (4-7) or cancer (8-11) as well as total mortality (12). Especially the risk for colon cancer, which is the second and third most frequent cancer worldwide in women and men, respectively (13) is dependent on lifestyle factors and nutrition (14) and can be reduced by nut consumption. Studies support an inverse relationship between nut consumption and the risk for colon cancer in women (9) as well as in men (15). Dietary fibers, which are abundant in nuts, may contribute to the beneficial effect on colon cancer risk. Several studies demonstrated that the consumption of dietary fiber or fiber rich foods is inversely associated with the risk for colon cancer development $(16,17)$. Especially hazelnuts, one of the most popular nuts consumed worldwide, belong to the nut varieties which are rich in dietary fiber $(3,18)$. A portion of $30 \mathrm{~g}$ nuts per day, which also reflects the daily recommended intake of nuts by the WHO (19) can provide up to $10 \%$ of the recommended daily amount of dietary fiber of $30 \mathrm{~g} \mathrm{(20).} \mathrm{Hazelnuts} \mathrm{are} \mathrm{also} \mathrm{a}$ good source for $\alpha$-tocopherol and phenolic compounds, which also exert health promoting effects as reviewed by Alasalvar and Bolling (2). Only a minor part of hazelnuts is consumed raw, whereas roasted hazelnuts are preferred. Roasting improves sensory properties of the nuts due to the development of the typical flavor and crunchy texture (21, 22 ). The roasting process can also affect the chemical composition of hazelnuts including health promoting ingredients like tocopherol and phenolic compounds $(2,18)$. Recently, we demonstrated that different nut varieties including hazelnuts, which were subjected to an in vitro digestion and fermentation, exhibit chemopreventive effects in LT97 colon adenoma cells by increasing gene expression of antioxidant and phase II enzymes, inhibition of proliferation and induction of apoptosis (23). Similar results were obtained by Lux et al. (24) who investigated the chemopreventive potential of different nuts in HT29 colon 
carcinoma cells. Until now, there is no information if the roasting process has an impact on these chemopreventive effects. Therefore, the aim of the present study was to examine the influence of different roasting conditions on chemopreventive effects of in vitro fermented hazelnuts in LT97 colon adenoma cells regarding DNA damage, gene expression of antioxidant and phase II enzymes, proliferation and apoptosis.

\section{Materials and Methods}

Roasting of hazelnuts. Hazelnuts were obtained from Viba Sweets (Floh-Seligenthal, Germany, originally derived from Turkey). Roasting of hazelnuts was performed at laboratory scale in charges of $9.5 \mathrm{~kg}$ using a FRC-T.1 drum roaster (Probat, Emmerich am Rhein, Germany) as previously described (18). The following roasting conditions (RC) were applied to cover the minimum and maximum range of roasting temperatures and time periods usually used for industrial roasting of hazelnuts (25): $\mathrm{RC} 1=140.6^{\circ} \mathrm{C} / 25 \mathrm{~min}$, $\mathrm{RC} 2=155.1^{\circ} \mathrm{C} / 20 \mathrm{~min}$ and $\mathrm{RC} 3=180.4^{\circ} \mathrm{C} / 21 \mathrm{~min}$. Hazelnuts were stored in hermetically sealed bags at $4^{\circ} \mathrm{C}$ until use

In vitro digestion and fermentation of hazelnuts. In vitro digestion and fermentation of hazelnuts was performed as described previously (23). In brief, $2 \mathrm{~g}$ of raw and roasted hazelnuts were ground and reconstituted with anaerobic potassium phosphate buffer $(0.1 \mathrm{M}, \mathrm{pH}$ 7.0), incubated with $\alpha$-amylase (17.4 U/sample in $20 \mathrm{mM} \mathrm{NaH}{ }_{2} \mathrm{PO}_{4}$ ) and $\mathrm{NaCl}(0.85 \%)$ for $5 \mathrm{~min}$ and pepsin $(1.11 \mathrm{mg}$ in $0.94 \mathrm{ml} 20 \mathrm{mM}$ $\mathrm{HCl}, \mathrm{pH} 2.0$ ) for $2 \mathrm{~h}$ at $37^{\circ} \mathrm{C}$. Synergy $1{ }^{\circledR}$ (oligofructose-enriched inulin, Beneo, Mannheim, Germany), was used as positive control and a blank fermentation sample without hazelnuts served as negative control. Subsequently, samples were treated with an intestinal extract $(26 \mathrm{mg}$ pancreatin, $50 \mathrm{mg}$ oxgall in $5 \mathrm{ml}$ of $11 \mathrm{mM}$ bicarbonate buffer, $\mathrm{pH} 6.5$ ) and dialyzed (molecular weight cut off: 500-1,000 Da) under semi-anaerobic conditions $\left(6 \mathrm{~h}, 37^{\circ} \mathrm{C}\right)$. A feces inoculum mixture of at least three healthy donors was used to perform in vitro fermentation in an anaerobic atmosphere $\left(37^{\circ} \mathrm{C}, 24\right.$ h). After stopping fermentation at $4^{\circ} \mathrm{C}$, fermentation supernatants (FS) were obtained by centrifugation $(30 \mathrm{~min}, 4200 \times g$ and $15 \mathrm{~min}$, $4,200 \times g$ at $\left.4^{\circ} \mathrm{C}\right)$. Final FS were obtained by centrifugation $(15 \mathrm{~min}$ $10,300 \times g$ at $4^{\circ} \mathrm{C}$ ) and sterile filtration (pore size $0.22 \mu \mathrm{m}$ ). Aliquots of $\mathrm{FS}$ were stored at $-80^{\circ} \mathrm{C}$ until use

Cell culture. The human colon adenoma cell line LT97 (a kind gift from Professor B. Marian, Institute for Cancer Research, University of Vienna, Austria) was used for cell culture experiments. This cell line was established from a micro-adenoma and represents an early stage of colon tumor development (26). Culture conditions and properties of LT97 cells were already described in detail previously (27). Recently, an authentication of LT97 cells was performed by STR (short tandem repeat) profiling (Leibnitz-Institute DSMZ, German Collection of Microorganisms and Cell Cultures).

Determination of genotoxic and antigenotoxic effects. Potential genotoxic and antigenotoxic effects of hazelnut FS were analyzed using the Comet Assay as described previously (24, 28). LT97 cells were grown to a confluence of about $70 \%$, harvested and washed with PBS. The ViCell cell counter (Beckman Coulter,
Krefeld, Germany) was used to determine cell number and viability. After adjusting the cell number to $0.4 \times 10^{6}$, LT97 cells were incubated with different concentrations (2.5 and $5 \%)$ of FS from raw and roasted hazelnuts and controls (blank, Synergy ${ }^{\circledR}$ ) for $1 \mathrm{~h}$ at $37^{\circ} \mathrm{C}$. In addition, LT97 cells were challenged with $\mathrm{H}_{2} \mathrm{O}_{2}$ to analyze antigenotoxic effects. Therefore, $0.4 \times 10^{6}$ cells were incubated with hazelnut FS for $45 \mathrm{~min}$ at $37^{\circ} \mathrm{C}$ and subsequently co-incubation was carried out with $\mathrm{H}_{2} \mathrm{O}_{2}(75 \mu \mathrm{M})$ for additional $15 \mathrm{~min}$. For Comet Assay experiments $\mathrm{H}_{2} \mathrm{O}_{2}(75 \mu \mathrm{M}, 15 \mathrm{~min}$ at $37^{\circ} \mathrm{C}$ ) and PBS served as positive and negative controls, respectively. After treatment, LT97 cells were washed with PBS and adjusted to $0.2 \times 10^{6}$ cells which were mixed with $45 \mu 10.7 \%$ low-melting agarose (Biozym, Hessisch Oldendorf, Germany) and distributed onto microscopic slides coated with $0.5 \%$ normalmelting agarose (Biozym, Hessisch Oldendorf, Germany). Slides were placed in lysis solution $(10 \mathrm{mM}$ Tris- $\mathrm{HCl}, 100 \mathrm{mM}$ $\mathrm{Na}_{2}$ EDTA, $2.5 \mathrm{M} \mathrm{NaCl}, 10 \%$ DMSO, $1 \%$ Triton $\mathrm{X}-100, \mathrm{pH} 10$ ) for $60 \mathrm{~min}$ at $4^{\circ} \mathrm{C}$. Subsequently, slides were placed into a cooled electrophoresis chamber containing alkaline buffer (1 mM Na 2 EDTA, $300 \mathrm{mM} \mathrm{NaOH}$, pH 13) for $20 \mathrm{~min}$ and then they were electrophoresed for $20 \mathrm{~min}(20 \mathrm{~V}, 300 \mathrm{~mA}, 0.79 \mathrm{~V} / \mathrm{cm}$, $\left.4^{\circ} \mathrm{C}\right)$. Slides were washed with PBS $(3 \times 5 \mathrm{~min})$ for neutralization. After staining DNA with SYBR ${ }^{\circledR}$ Green (Sigma Aldrich, Munich, Germany) DNA damage was detected using a fluorescence microscope (ZEISS Axiostar plus; Carl Zeiss Jena GmbH) and image analysis system (Comet Assay IV, Perceptive Instruments, Suffolk, UK). The tail intensity (\% TI) was determined as degree of DNA damage as means of sixty cells.

Isolation of total RNA. LT97 cells were treated with FS from raw and roasted hazelnuts $(2.5 \%$ and $5 \%)$ and controls as well as butyrate $(4 \mathrm{mM})$ as further positive control for $24 \mathrm{~h}$. The RNeasy Plus Mini kit (Qiagen, Hilden, Germany) was used to isolate total RNA according to the manufacturer's instructions. Elution of RNA was performed in $50 \mu \mathrm{l}$ RNase-free water. The Quality and concentrations of total RNA were measured with a NanoDropND1000 photometer (NanoDrop Technologies, Wilmington, Delaware, USA). In addition, the RNA integrity number (RIN) was determined using the Agilent RNA 6000 Nano Kit (Agilent Technologies, Santa Clara, California, USA) and the Agilent 2100 Bioanalyzer (Agilent Technologies, Waldbronn, Germany) according to the manufacturer's instructions. Only RNA samples with a RIN $>9$ were used for experiments. RNA was stored at $-80^{\circ} \mathrm{C}$ until use.

cDNA synthesis and mRNA expression. Complimentary DNA was obtained via reverse transcription of $1.5 \mu \mathrm{g}$ total RNA in a $20 \mu \mathrm{l}$ reaction mix $\left(42^{\circ} \mathrm{C}, 50 \mathrm{~min}\right)$ using the SCRIPT Reverse Transcriptase kit (Jena Bioscience, Jena, Germany). The samples were heated to $72^{\circ} \mathrm{C}$ for $15 \mathrm{~min}$ to stop the reaction and remaining RNA was removed by treatment with $\mathrm{RNaseH}\left(37^{\circ} \mathrm{C}, 20 \mathrm{~min}\right)$. For further experiments, cDNA samples were diluted (1:50) in RNase free water. The mRNA expression of antioxidant and phase II enzymes (CAT, SOD2, GPX1 and GSTP1) was analyzed by RTqPCR as described previously using the GoTaq ${ }^{\circledR}$ qPCR Master Mix (Promega, Mannheim, Germany) and the iCycler iQ Real time PCR Detection System (Bio-Rad Laboratory, Munich, Germany) as well as gene specific primers (23). The expression of CAT, SOD2, GPXI and GSTP1 was normalized to the geometric mean of two reference genes $\beta$-actin and GAPDH based on the equation of Pfaffl et al. (29) and expressed as fold change (fc). 
a

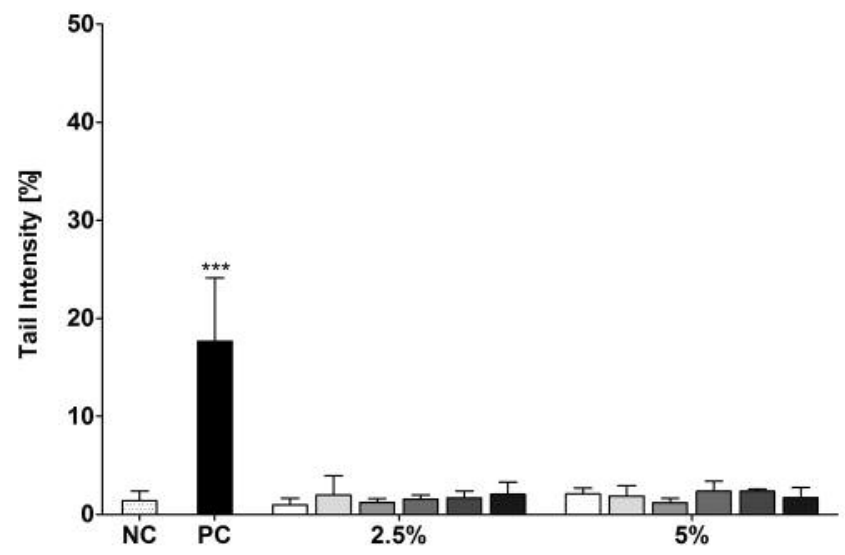

b

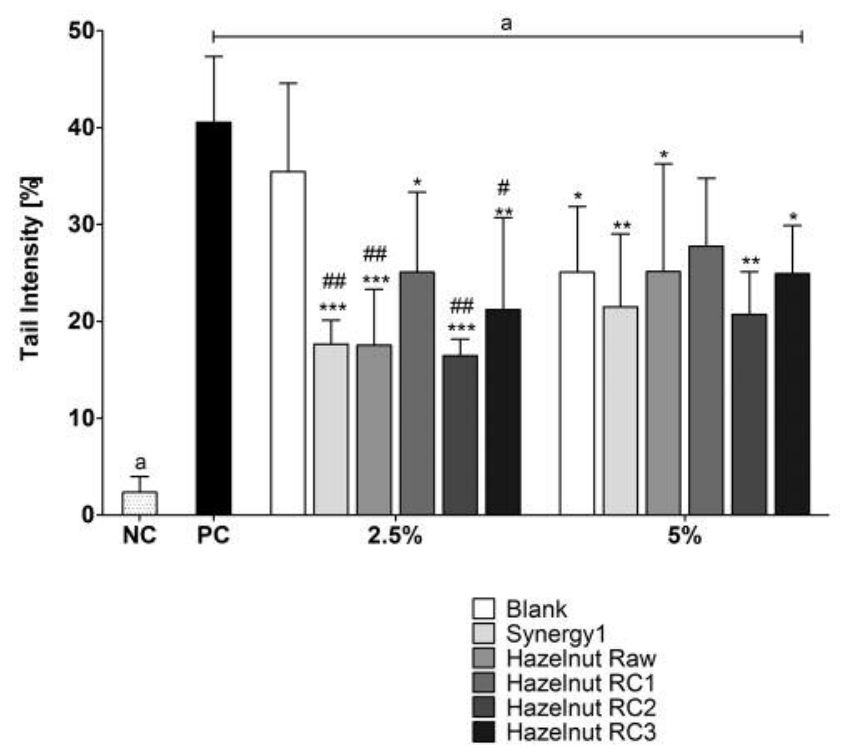

Figure 1. Genotoxic (a) and antigenotoxic (b) effects of fermentation supernatants (FS, 2.5 and $5 \%$ ) of raw and roasted hazelnuts $\left(R C 1=140.6^{\circ} \mathrm{C} / 25\right.$ min, $R C 2=155.1^{\circ} \mathrm{C} / 20 \mathrm{~min}$ and $\mathrm{RC} 3=180.4^{\circ} \mathrm{C} / 21 \mathrm{~min}$ ) and controls (blank, Synergy $1^{\circledR}$ ) for $1 \mathrm{~h}$ in LT97 colon adenoma cells (mean $\left.+S D, n=3\right)$. Significant differences between FS from raw and roasted hazelnuts as well as Synergy ${ }^{\circledR}$ and the positive control $\left(P C, 75 \mu M \mathrm{H}_{2} \mathrm{O}_{2},{ }^{*} p \leq 0.05\right.$, ${ }^{* *} p \leq 0.01$, ***p $\left.\leq 0.001\right)$, the negative control (NC, PBS, $\left.{ }_{p} p \leq 0.05\right)$ and the blank control $\left(\# \leq \leq 0.05,{ }^{\#} p \leq 0.01\right)$ were obtained by two-way Anova/Bonferroni post-test.

Determination of cell growth. To analyze growth inhibitory effects of hazelnut FS, LT97 colon adenoma cells were treated with different concentrations of FS from raw and roasted hazelnuts $(2.5,5,10$ and $20 \%)$ for 24,48 and $72 \mathrm{~h}$. The DAPI (4',6-diamidino-2-phenylindol) assay was used to determine the time- and dose-dependent effects on growth of LT97 cells as described previously (30).

Detection of apoptosis. LT97 cells were grown to a confluence of about $70 \%$ and treated with different concentrations (2.5 and 5\%) of FS from raw and roasted hazelnuts and controls as well as butyrate $(4 \mathrm{mM})$ for 12 and $24 \mathrm{~h}$. Quantification of early apoptotic cells was performed via flow cytometry (Cell Lab Quanta ${ }^{\mathrm{TM}} \mathrm{SC}$ MPL 1.0, Beckman Coulter, Krefeld, Germany) using the annexin V-FITC/7-AAD (fluorescein isothiocyanate/7-aminoactinomycin D) kit (Beckman Coulter, Krefeld, Germany) according to the manufacturer's instructions. In addition, caspase-3 activity as marker of advanced apoptosis was analyzed in LT97 cells treated with hazelnut FS and fermentation controls (2.5 and 5\%) for 24 and $48 \mathrm{~h}$ as well as butyrate $(4 \mathrm{mM})$ as described by Borowicki et al. (31). Relative caspase activities were calculated as fold changes on the basis of the medium control, which was set to 1 .

Statistical analysis. Means and standard deviations of three independent experiments were calculated. Statistical differences were analyzed by one- or two-way ANOVA including Bonferroni post-test or Student's $t$-test for comparison of two groups using GraphPad Prism ${ }^{\circledR}$ version 5 for Windows (GraphPad Software, San Diego, California, USA).

\section{Results}

Determination of genotoxic and antigenotoxic effects. Genotoxic and antigenotoxic effects of FS from raw and differentially roasted hazelnuts in LT97 colon adenoma cells were determined via Comet Assay. With an average tail intensity of $1.8 \pm 0.5 \%$ hazelnut FS proved to be nongenotoxic (Figure 1a). These results were comparable to tail intensities determined for cells treated with FS from the blank control $(1.6 \pm 0.8 \%)$, FS from Synergy $1{ }^{\circledR}(1.9 \pm 0.1 \%)$ as well as the negative control (PBS, $1.4 \pm 0.9 \%$ ). In comparison, the tail intensity was significantly higher after treatment with the positive control $(17.7 \pm 6.4 \%)$. These results indicate, that no DNA damage was induced by hazelnut FS and that the roasting process had no impact on a potential genotoxicity of hazelnut FS. Co-incubation of LT97 cells with FS from raw and roasted hazelnuts and controls together with $\mathrm{H}_{2} \mathrm{O}_{2}$ reduced the levels of $\mathrm{H}_{2} \mathrm{O}_{2}$-induced DNA damage (Figure 1b). Especially, treatment with $2.5 \%$ FS from Synergy $1{ }^{\circledR}$ $(17.7 \pm 2.5 \%)$, hazelnut raw $(17.6 \pm 5.7 \%)$ as well as $\mathrm{RC} 2$ $(16.5 \pm 1.7 \%)$ and $\mathrm{RC} 3(21.2 \pm 9.5 \%)$ resulted in significantly reduced levels of DNA damage compared to the positive control $(40.5 \pm 6.8 \%)$ and the FS from the blank control $(35.4 \pm 9.1 \%)$. Significantly lower tail intensities compared to the positive control could also be observed after treatment 

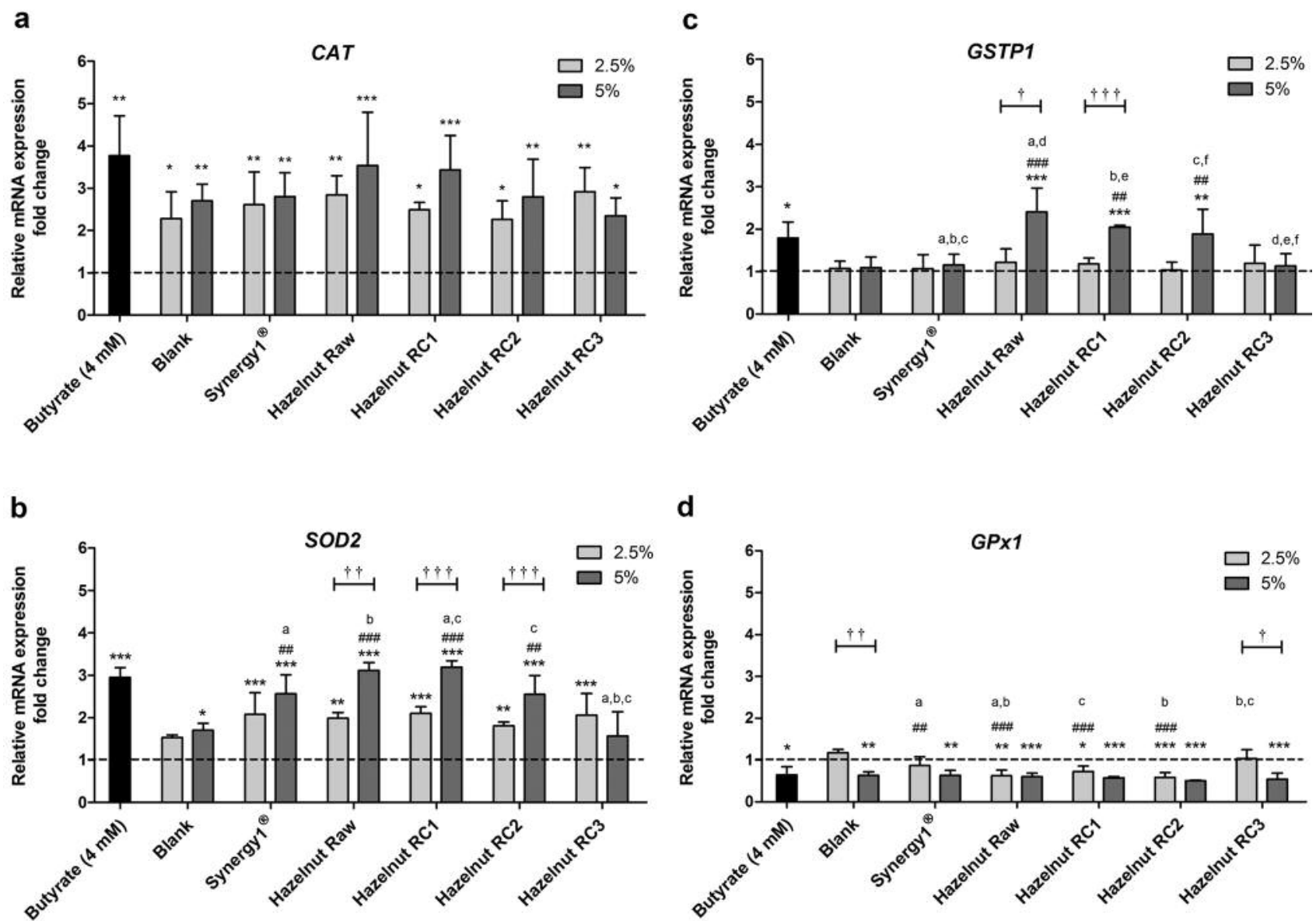

Figure 2. Relative mRNA expression of a) CAT (catalase), b) SOD2 (superoxide dismutase 2), c) GSTP1 (glutathione S-transferase P1), and d) GPX1 (glutathione peroxidase 1) in LT97 colon adenoma cells after incubation with fermentation supernatants (FS, 2.5 and $5 \%$ ) of raw and roasted hazelnuts $\left(R C 1=140.6^{\circ} \mathrm{C} / 25 \mathrm{~min}, R C 2=155.1^{\circ} \mathrm{C} / 20 \mathrm{~min}\right.$ and $\left.R C 3=180.4^{\circ} \mathrm{C} / 21 \mathrm{~min}\right)$ and controls $\left(4 \mathrm{mM}\right.$ butyrate, blank, Synergyl $\left.{ }^{\circledR}\right)$ for $24 \mathrm{~h}$ $($ mean $+S D, n=3)$. Values represent fold changes on the basis of a medium control (set as 1, dashed line). Significant differences compared to the medium control $\left(* p \leq 0.05, *^{*} p \leq 0.01, *^{* *} p \leq 0.001\right)$, to the blank control ${ }^{*}{ }^{*} p \leq 0.01$, \#\#\# $\left.\leq 0.001\right)$ and between $F S\left(a-f_{p} \leq 0.05\right.$, equal letters represent significant differences) were obtained by two-way Anova/Bonferroni post-test. Significant differences between 2.5 and $5 \%$ were obtained by unpaired Student's $t$-test $\left({ }^{\dagger} p \leq 0.05,{ }^{\dagger} p \leq 0.01,{ }^{\dagger \dagger} p \leq 0.001\right)$.

with $5 \%$ FS from raw and roasted hazelnuts $(23.0 \pm 2.6 \%$ on average, except RC1) as well as the FS of the blank $(25.1 \pm 6.8 \%)$ and FS of the Synergy $1{ }^{\circledR}$ control $(21.5 \pm 7.5 \%)$.

Modulation of selected target genes in LT97 cells by hazelnut FS. Expression levels of mRNA of CAT, SOD2, GPXI and GSTP1 were examined in LT97 cells treated with FS from raw and differentially roasted hazelnuts and controls using RT-qPCR. A significant induction of $C A T$ mRNA levels in comparison to the medium control (set as 1) could be measured after treatment with FS from raw and roasted hazelnuts (FS $2.5 \%$ fc: $2.5 \pm 0.5$, FS $5 \%$ fc: $3.0 \pm 0.9$, on average) and FS from blank (FS $2.5 \%$ fc: $2.3 \pm 0.6$, FS $5 \%$ fc: $2.7 \pm 0.4)$ as well as Synergy $1{ }^{\circledR}$ (FS $2.5 \%$ fc: $2.6 \pm 0.8$, FS
$5 \%$ fc: $2.8 \pm 0.6$ ) (Figure $2 \mathrm{a})$. Butyrate $(4 \mathrm{mM})$, which served as a positive control, also significantly increased levels of $C A T$ mRNA (fc: $3.8 \pm 0.9$ ) in a similar manner. Levels of SOD2 mRNA were also significantly induced by all hazelnut FS (FS $2.5 \%$ fc: $2.0 \pm 0.3$, FS $5 \%$ fc: $2.6 \pm 0.8$, on average) and FS obtained from Synergy $1{ }^{\circledR}$ (FS $2.5 \%$ fc: $2.1 \pm 0.5$, FS $5 \%$ fc: $2.6 \pm 0.4$ ) as well as butyrate (fc: $2.9 \pm 0.2$ ) in comparison to the medium control (Figure 2b). In particular, treatment with 5\% FS from raw hazelnuts (fc: 3.1 \pm 0.2 ), RC1 (fc: $3.2 \pm 0.1$ ) and RC2 (fc: $2.6 \pm 0.4$ ) as well as Synergy $1{ }^{\circledR}$ resulted in dose-dependently and significantly higher SOD2 mRNA levels compared to the blank control (fc: $1.7 \pm 0.2$ ). These SOD2 mRNA levels were also significantly higher compared to the treatment with FS 
obtained from the most intensively roasted hazelnuts (FS

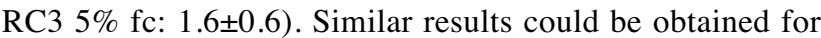
GSTP1 mRNA expression (Figure 2c). Here, treatment with $5 \%$ FS from raw (fc: $2.4 \pm 0.6$ ) and roasted hazelnuts RC1 (fc: $2.0 \pm 0.0$ ) and RC2 (fc: $1.9 \pm 0.6$ ) led to a significant increase of GSTP1 mRNA levels compared to the medium control as well as the respective FS from the blank control (fc: $1.1 \pm 0.3$ ), Synergy $1{ }^{\circledR}$ (fc: $1.2 \pm 0.3$ ) and the most intensively roasting condition RC3 (fc: $1.1 \pm 0.3$ ). In general, the induction of GSTP 1 by hazelnut FS was comparable to the induction caused by butyrate (fc: $1.8 \pm 0.4$ ). In contrast to all other genes, GPxl mRNA expression was significantly reduced by almost all FS, especially after treatment with $5 \%$ FS from raw and roasted hazelnuts (fc: $0.6 \pm 0.1$, on average), butyrate (fc: $0.6 \pm 0.2$ ), Synergy $1{ }^{\circledR}$ (fc: $0.6 \pm 0.2$ ) and also the blank control (fc: $0.6 \pm 0.1$ ) (Figure 2d). Treatment of LT97 cells with $2.5 \%$ FS from Synergy $1{ }^{\circledR}$ (fc: $0.9 \pm 0.2$ ) and particularly FS from raw (fc: $0.6 \pm 0.1$ ) and roasted hazelnuts RC1 (fc: $0.7 \pm 0.1$ ) and RC2 (fc: $0.6 \pm 0.1$ ) resulted in significantly reduced GPxl levels compared to the respective blank control (fc: $1.2 \pm 0.1$ ) as well as FS RC3 (fc: $1.0 \pm 0.2$ ).

Inhibition of LT97 cell growth by hazelnut FS. Treatment of LT97 cells with FS from raw and roasted hazelnuts as well as controls led to a significant reduction of cell growth in a time- and dose-dependent manner (Figure 3). After $24 \mathrm{~h}$, the average LT97 cell number was already significantly reduced to $63.2 \pm 4.0 \%$ and $48.5 \pm 5.0 \%$ upon treatment with 2.5 and $20 \%$ FS from raw and roasted hazelnuts, respectively in comparison to the medium control which was set to $100 \%$ (Figure 3a). In comparison, especially FS from Synergy $1{ }^{\circledR}$ exhibited stronger growth inhibitory effects which ranged from $62.3 \pm 6.1 \%$ to $11.4 \pm 10.8 \%$ after treatment with 2.5 to $20 \%$, respectively. The strongest growth inhibitory potential of hazelnut FS were detectable after 48 and $72 \mathrm{~h}$. Treatment of LT97 cells with $2.5-20 \%$ hazelnut FS for $48 \mathrm{~h}$ resulted in an average growth reduction ranging between $44.3 \pm 6.2 \%$ and $11.5 \pm 4.1 \%$ (Figure $3 \mathrm{~b}$ ). Almost similar cell numbers could be measured after treatment with FS (2.5-20\%) from Synergy $1{ }^{\circledR}(48.3 \pm 1.7 \%$ to $1.9 \pm 1.1 \%)$, while the blank FS reduced cell growth in the range from $62.6 \pm 1.5 \%$ and $3.1 \pm 1.7 \%$ (2.5 and $20 \%$, respectively). In addition, treatment with $2.5 \%$ and $5 \%$ FS from Synergy $1{ }^{\circledR}$ resulted in significantly lower cell growth $(14.4 \%$ and $12.6 \%$, respectively) than the respective blank control. Similar results were obtained after treatment with $2.5 \%$ and $5 \%$ FS from hazelnuts which led to significantly lower cell numbers $(18.3 \pm 3.1 \%$ and $12.3 \pm 1.4 \%$, respectively) than the respective blank control. Comparable results were obtained after treatment with $2.5 \%$ and $5 \%$ FS from Synergy ${ }^{\circledR}$ and hazelnuts for $72 \mathrm{~h}$, which also led to significantly lower cell numbers in comparison to FS from the respective blank control (Figure 3c). In general, cell growth at this time point ranged between $64.0 \pm 3.4 \%$ and $0.7 \pm 0.6 \%$ after treatment with FS blank (2.5-20\%), between $52.7 \pm 4.6 \%$ and $1.8 \pm 0.7 \%$ after treatment with FS Synergy $1{ }^{\circledR}(2.5-20 \%)$ and between $49.4 \pm 6.4 \%$ and $1.9 \pm 1.8 \%$ on average after treatment with hazelnut FS (2.5-20\%). In general, no differences between raw or roasted nuts could be observed regarding their growth inhibitory potential.

Induction of apoptosis in LT97 cells by hazelnut FS. Examination of early apoptotic processes mediated by fermented hazelnut samples via annexin V-FITC/7-AAD staining and flow cytometry revealed that FS from roasted hazelnuts RC1 (FS 5\%: 7.9 $\pm 3.3 \%$ ) and RC2 (FS 2.5\%: $6.7 \pm 2.7 \%$ ) were able to significantly enhance the number of apoptotic cells after treatment for $12 \mathrm{~h}$ (Figure 4a) in comparison to the medium control $(2.4 \pm 1.3 \%)$ as well as the

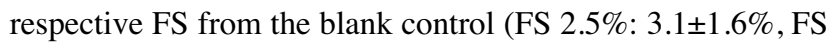
$5 \%: 3.8 \pm 0.3 \%$ ) and Synergy $1{ }^{\circledR}$ (FS $2.5 \%: 2.9 \pm 0.5 \%$, FS $5 \%$ : $4.1 \pm 2.3 \%)$. The increase of early apoptotic cells was more pronounced after $24 \mathrm{~h}$ and largely dose-dependent (Figure $4 \mathrm{~b}$ ). At this time point, mainly 5\% FS from raw and roasted hazelnuts $(9.6 \pm 0.9 \%$, on average), the blank control $(6.8 \pm 3.1 \%)$ and Synergy $1^{\circledR}(6.6 \pm 1.0 \%)$ as well as butyrate $(5.8 \pm 0.8 \%)$, which served as positive control, significantly increased the number of early apoptotic cells in comparison to the medium control $(2.9 \pm 1.0 \%)$. In addition, $2.5 \%$ and $5 \%$ FS from roasted hazelnuts $\mathrm{RC} 1$ and $\mathrm{RC} 2$ also significantly enhanced the number of apoptotic cells compared to the respective blank control.

In addition, caspase- 3 activity as a marker of advanced apoptosis was significantly enhanced in a dose-dependent manner in LT97 cells after treatment with FS from raw and roasted hazelnuts (FS $2.5 \%$ fc: $3.3 \pm 0.8$, FS $5 \%$ fc: $6.4 \pm 1.4$, on average) as well as Synergy $1{ }^{\circledR}$ (FS $2.5 \%$ fc: $3.4 \pm 0.4$, FS $5 \%$ fc: $5.8 \pm 0.6$ ) and butyrate (fc: $6.5 \pm 0.9$ ), especially after $24 \mathrm{~h}$ (Figure 5a). In contrast, FS from the blank control was not able to induce caspase- 3 activity (FS $2.5 \%$ fc: $1.4 \pm 0.2$, FS 5\% fc: $1.7 \pm 0.2$ ) resulting in significantly increased caspase- 3 activities after treatment with all fermented hazelnut samples (except FS RC3 2.5\%) in comparison to the FS of the blank. Levels of caspase-3 activity were significantly higher after treatment with hazelnut FS from the most intense roasting condition than after incubation with FS from raw or more weakly roasted hazelnuts RC1. Treatment of LT97 for $48 \mathrm{~h}$ resulted in lower caspase-3 activities compared to the $24 \mathrm{~h}$ treatment (Figure 5b). But, butyrate (fc: $4.9 \pm 1.0$ ) and 5\% FS from hazelnuts (fc: $4.4 \pm 1.0$, on average) and Synergy $1{ }^{\circledR}$ (fc: $4.3 \pm 1.3$ ) were able to significantly enhance caspase- 3 activity compared to the medium and also to the respective blank control (fc: $0.9 \pm 0.3$ ), whereas in general no induction of caspase- 3 was detectable for treatment with $2.5 \%$ FS. 

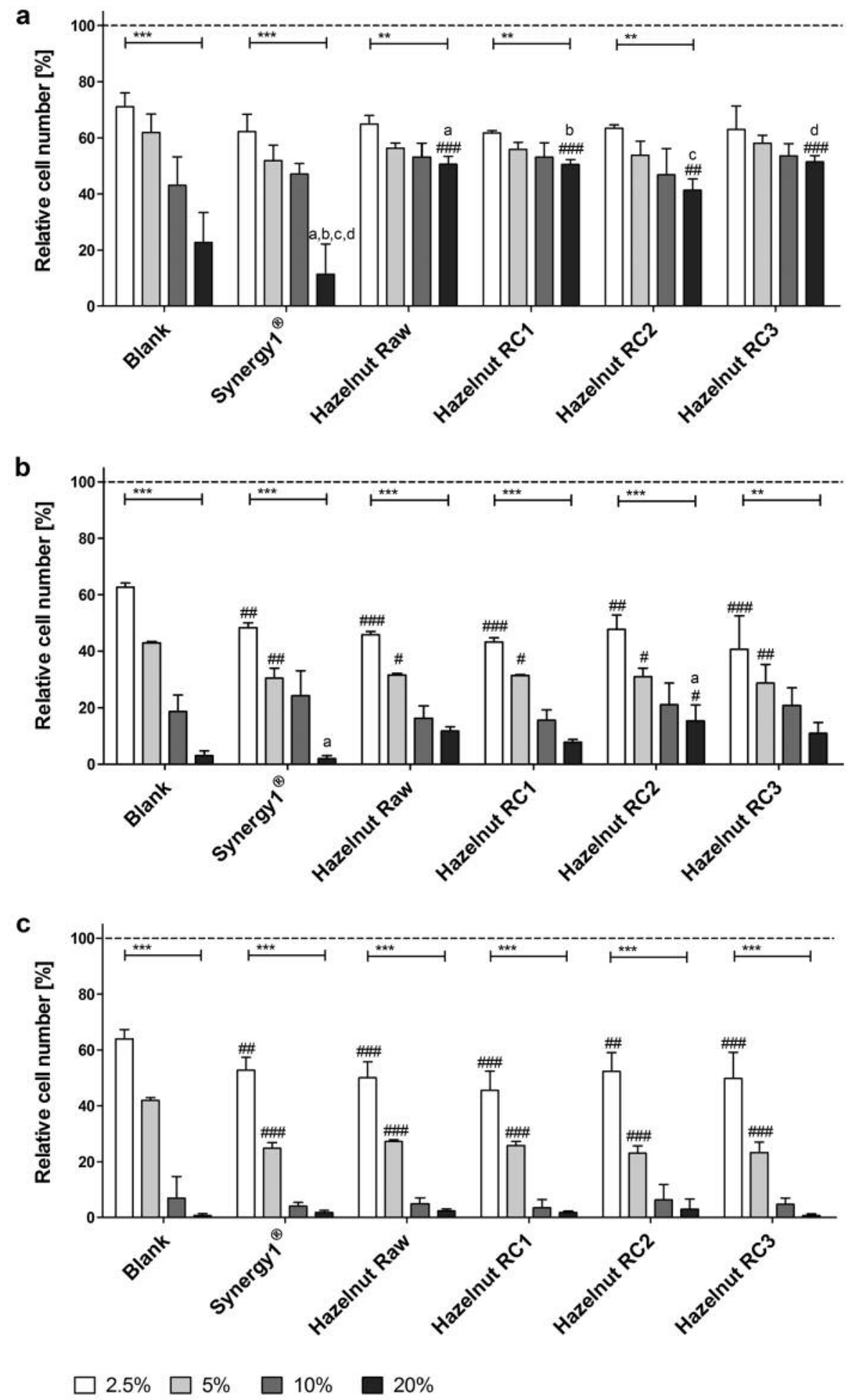

Figure 3. Growth inhibition of LT97 colon adenoma cells after incubation with fermented samples of raw and roasted hazelnuts $\left(R C 1=140.6^{\circ} \mathrm{C} / 25 \mathrm{~min}\right.$, $R C 2=155.1^{\circ} \mathrm{C} / 20 \mathrm{~min}$ and $R C 3=180.4^{\circ} \mathrm{C} / 21 \mathrm{~min}$ ) and controls (blank, Synergyl ${ }^{\circledR}$ ) in concentrations of $2.5-20 \%$ for a) $\left.24 \mathrm{~h}, \mathrm{~b}\right) 48 \mathrm{~h}$, and c) $72 \mathrm{~h}$ (mean $\pm S D, n=3)$. Significant differences between blank and fermentation supernatants $(F S)$ of Synergy ${ }^{\circledR}$ or hazelnuts $\left({ }^{\#} p \leq 0.05\right.$, \#\# $p \leq 0.01$, \#\#\# $\left.p \leq 0.001\right)$ were obtained by two-way Anova/Bonferroni post-test. Significant differences between different concentrations $(* * p \leq 0.01$, ***p $\leq 0.001)$ were obtained by one-way Anova/Bonferroni post-test. All fermentation samples were significantly different compared to the medium control which was set to 100\% (dashed line). 

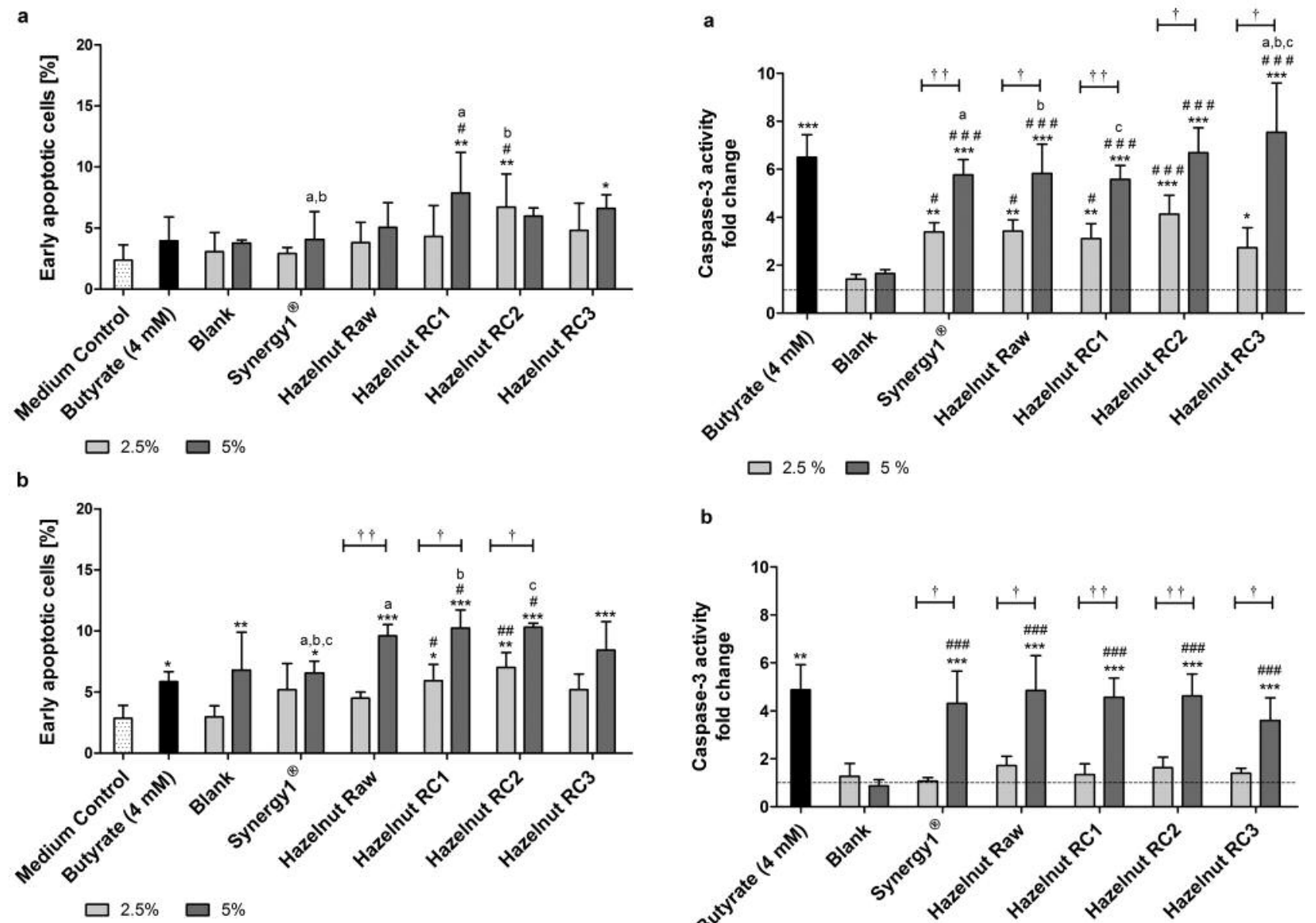

Figure 4. Number of early apoptotic LT97 cells in percent after incubation with fermentation supernatants (FS, 2.5 and $5 \%$ ) of raw and roasted hazelnuts $\left(R C 1=140.6^{\circ} \mathrm{C} / 25 \mathrm{~min}, R C 2=155.1^{\circ} \mathrm{C} / 20 \mathrm{~min}\right.$ and $\left.R C 3=180.4^{\circ} \mathrm{C} / 21 \mathrm{~min}\right)$ and controls $\left(4 \mathrm{mM}\right.$ butyrate, Synergy $1^{\circledR}$, blank $)$ for a) $12 h$ and b) $24 h$ (mean $+S D, n=3)$. Significant differences compared to the medium control $(* p \leq 0.05, * * p \leq 0.01$, ***p $\leq 0.001)$, to the blank control $\left({ }^{\#} p \leq 0.05,{ }^{\#} p \leq 0.01\right)$ and between FS $\left({ }^{a-c} p \leq 0.05\right.$, equal letters represent significant differences) were obtained by two-wayAnova/Bonferroni post-test. Significant differences between 2.5 and $5 \%$ were obtained by unpaired Student's t-test $\left({ }^{\dagger} p \leq 0.05,{ }^{\dagger} p \leq 0.01\right)$.

\section{Discussion}

The influence of different roasting conditions on potential chemopreventive effects of in vitro digested and fermented hazelnuts regarding colon cancer development was examined in the present study. An initial step of chemoprevention is the reduction of potential carcinogens like reactive oxygen species (ROS) that can cause DNA damage in colon cells (32). The results from the present study demonstrate that FS from hazelnuts are able to reduce the level of DNA damage

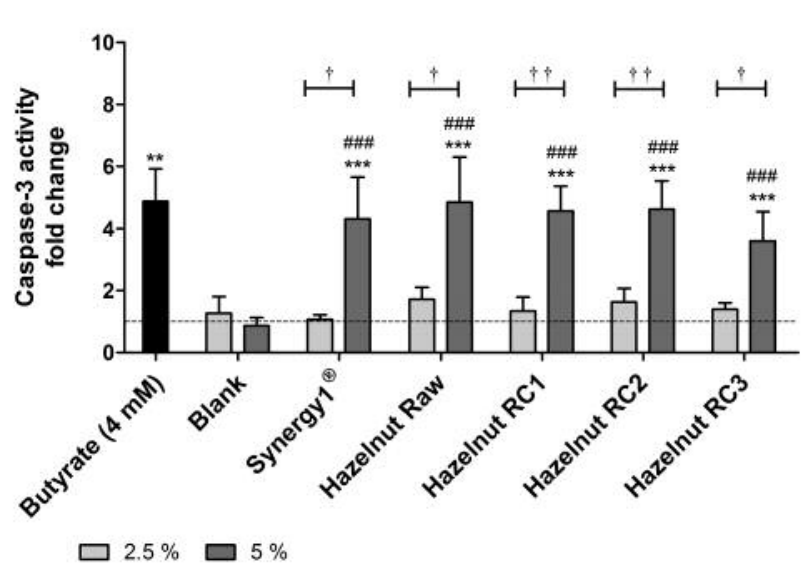

Figure 5. Caspase-activity in LT97 cells after incubation with fermentation supernatants (FS, 2.5 and $5 \%$ ) of raw and roasted hazelnuts $\left(R C 1=140.6^{\circ} \mathrm{C} / 25 \mathrm{~min}, R C 2=155.1^{\circ} \mathrm{C} / 20 \mathrm{~min}\right.$ and $\left.R C 3=180.4^{\circ} \mathrm{C} / 21 \mathrm{~min}\right)$ and controls ( $4 \mathrm{mM}$ butyrate, Synergyl ${ }^{\circledR}$, blank) for a) $24 \mathrm{~h}$ and b) $48 \mathrm{~h}$ (mean $+S D, n=3)$. Values represent fold changes on the basis of a medium control (set as 1, dashed line). Significant differences compared to the medium control $(* p \leq 0.05, * * p \leq 0.01, * * * p \leq 0.001)$, to the blank control $\left({ }^{\#} p \leq 0.05, " \# \# \leq 0.001\right)$ and between $F S\left({ }^{a-c} p \leq 0.05\right.$, equal letters represent significant differences) were obtained by two-way Anova/Bonferroni posttest. Significant differences between 2.5 and $5 \%$ were obtained by unpaired Student's t-test $\left({ }^{\dagger} p \leq 0.05,{ }^{\dagger} p \leq 0.01\right)$.

in LT97 colon adenoma cells challenged with $\mathrm{H}_{2} \mathrm{O}_{2}$. The reduction of DNA damage after short-term treatment could be the result of antioxidant active compounds from hazelnuts or metabolites formed during fermentation. In general, nuts and especially hazelnuts are rich in bioactive phytochemicals like phenolic acid, proanthocyanidins, flavonoids and $\alpha$ tocopherol, which each exert antioxidant activities (2). Studies indicate that roasting of nuts (33) or hazelnuts (34), respectively, is associated with a loss of these bioactive compounds resulting in lower antioxidant capacities. In the 
present study, no distinct influence of the roasting process could be observed regarding the reduction of DNA damage. This is in line with results from a former study showing relative stable hydrophilic antioxidant capacities for hazelnuts after roasting with different time and temperature ranges (18).

Protection from excessive ROS accumulation is also mediated by antioxidant and phase II enzymes. The present study showed that hazelnut FS are able to significantly induce gene expression of such enzymes like CAT, SOD2 and GSTP1 in LT97 colon cells. Especially, SOD2 and GSTP1 were inducible by hazelnut FS in comparison to the blank control, whereas GPXI was mostly significantly down-regulated. Similar results were obtained in a recent study which analyzed the expression of theses enzymes in LT97 cells after treatment with FS from different raw nut varieties (23). Levels of mRNA after treatment with hazelnut FS were similar to that after butyrate treatment, indicating that the induction of these enzymes may be mainly mediated by this fermentation product of hazelnut dietary fiber. In a recent study we have demonstrated the production of short chain fatty acids (SCFA) and especially butyrate in fermented nut samples (35). Former studies also indicated that butyrate as the key fermentation product of dietary fiber is responsible for the induction of genes encoding CAT, GSTS or SOD (3639). An induction of CAT and GSTP1 in HT29 colon carcinoma cells upon incubation with fermentation products from fiber rich sources like wheat aleurone was also observed by Stein et al. (40). The induction of antioxidant and phase II enzymes by butyrate may be mainly mediated by its function as histone deacetylase inhibitor $(38,39,41)$ or via association with increased levels of NF-E2-related factor 2 (42). This transcription factor, which can be activated by many dietary compounds such as flavonoids and polyphenols, regulates the expression of many antioxidant and phase II enzymes via antioxidant response elements (ARE) (32). Therefore, in addition to butyrate, other hazelnut compounds like flavonoids or polyphenols may contribute to the induction of antioxidant and phase II genes. Metabolites of phenolic compounds resulting from fermentation in the colon might also induce antioxidant or phase II enzymes. Metabolites of quercetin and chlorogenic acid/caffeic acid (3,4-dihydroxyphenylacetic acid and 3-(3,4dihydroxyphenyl)-propionic acid, respectively) for example, induced GSTT2 gene expression in LT97 cells and also reduced cumene hydroperoxide-induced DNA damage (43).

The impact of hazelnut FS on gene expression of SOD2, GSTP1 and GPXl was lower for FS resulting from hazelnuts which were roasted with the most intense condition (RC3). This reduction could be due to the loss of antioxidants like phenolic compounds which could activate ARE. Such antioxidants are predominantly located in the pellicle of hazelnuts, which can be removed upon roasting with high roasting temperatures and duration $(34,44)$.
Mechanisms of secondary chemoprevention include the induction of apoptosis and reduction of proliferation of initiated cells (39). The present study demonstrates that fermented hazelnuts are able to significantly reduce the growth of LT97 adenoma cells in a time- and dose-dependent manner independently of the roasting process. These results are confirmed by former studies, which revealed growth inhibitory effects of FS from different raw nut varieties including hazelnuts in LT97 (23) and HT29 cells (24). In addition, the FS from other dietary fiber sources like wheat aleurone $(31,45)$ or bread (30) also exhibited growthinhibitory potential on LT97 cells. These growth inhibitory effects of nuts and other dietary fiber rich foods are to a large part mediated by metabolites like butyrate and to some extend also propionate, which are formed during fermentation of dietary fiber $(30,41,45,46)$. In a recent study we have confirmed that fermentation of hazelnuts results in the formation of these SCFA (35). In contrast, the blank control representing the pure feces matrix, contained only minor amounts of SCFA or butyrate, respectively. Here, the growth inhibitory effects might be mediated by high concentrations of bile acids like deoxycholic acid measured especially in the FS blank $(35,47)$.

The present study also revealed an induction of apoptosis in LT97 cells by FS from raw and roasted hazelnuts as shown by an increase in early apoptotic cells and an induction of caspase- 3 activity. These apoptotic effects may be mainly responsible for the observed growth inhibition triggered by hazelnut FS. Similar results were obtained in a recent study with FS from different raw nut varieties including hazelnuts (23). In addition, results from other studies show an induction of apoptosis in HT29 and LT97 cells by FS from different dietary fiber rich sources (30, 31, 45). The apoptotic effects, caused by hazelnut FS were similar to or even higher than levels observed for butyrate or the fermentation control Synergy $1^{\circledR}$, indicating that butyrate is mainly responsible for the induction of apoptosis. Butyrate can exhibit pro-apoptotic potential via several mechanisms including its function as a histone deacetylase inhibitor $(38,39,41)$, activation of the death receptor 5 (48), TGF- $\beta_{1}$ (49), the JNK MAP (50) and mitochondrial pathways (51), as well as the induction of the WNT pathway (52). In addition to butyrate, several compounds can be formed during in vitro digestion and fermentation of hazelnuts, which may contribute to the apoptotic potential such as phenolic acids, flavonoids, lignans or phytosterols $(33,53-55)$.

In summary, the results from the present study demonstrate the chemopreventive potential of in vitro digested and fermented hazelnuts. While genes involved in elimination of ROS or carcinogens are only induced by raw or mildly roasted hazelnuts, the inhibition of cell growth as well as the induction of apoptosis in colon adenoma cells was not 
affected by the roasting process. The proof that roasting has no concrete diminishing effect on chemopreventive properties of hazelnuts is an important finding since hazelnuts are often consumed roasted.

In conclusion, the consumption of raw and also moderateroasted hazelnuts might be associated with a lower risk for colon cancer development.

\section{Conflicts of Interest}

The Authors declare that they have no competing interests.

\section{Acknowledgements}

The Authors would like to thank the Probat-Werke von Gimborn Maschinenfabrik $\mathrm{GmbH}$ for roasting the nuts, especially Thomas Koziorowski and Thomas Elshoff. The Authors would also like to express their gratitude to Gudrun Steinmetzer for her excellent technical assistance and Christian Saupe for performing growth inhibition experiments. This IGF project (AiF $16642 \mathrm{BR}$ ) of the FEI (Research Association of the German Food Industry) was supported via AiF (German Federation of Industrial Research Associations) within the program for promoting the Industrial Collective Research (IGF) of the German Ministry of Economics and Energy (BMWi), based on a resolution of the German Parliament. Nucis e.V. Germany funded the project, too.

\section{References}

1 World Health Organization (WHO). World Health Statistics 2016 - Monitoring Health for the SDGs (sustainable development goals). Geneva, Switzerland, 2016.

2 Alasalvar C and Bolling BW: Review of nut phytochemicals, fat-soluble bioactives, antioxidant components and health effects. Br J Nutr 113(Suppl 2): S68-S78, 2015.

3 Ros E: Health benefits of nut consumption. Nutrients 2: $652-$ 682, 2010

4 Del Gobbo LC, Falk MC, Feldman R, Lewis K and Mozaffarian D: Effects of tree nuts on blood lipids, apolipoproteins, and blood pressure: systematic review, meta-analysis, and doseresponse of 61 controlled intervention trials. Am J Clin Nutr 102: 1347-1356, 2015.

5 Fischer Sand Glei M: Health-Potential of Nuts. Ernaehrungs Umschau international 60: 206-215, 2013.

6 Kendall CW, Josse AR, Esfahani A and Jenkins DJ: Nuts, metabolic syndrome and diabetes. Br J Nutr 104: 465-473, 2010

7 Viguiliouk E, Kendall CW, Blanco MS, Cozma AI, Ha V, Mirrahimi A, Jayalath VH, Augustin LS, Chiavaroli L, Leiter LA, de Souza RJ, Jenkins DJ and Sievenpiper JL: Effect of tree nuts on glycemic control in diabetes: a systematic review and meta-analysis of randomized controlled dietary trials. PLoS One 9: e103376, 2014

8 Bao Y, Hu FB, Giovannucci EL, Wolpin BM, Stampfer MJ, Willett WC and Fuchs CS: Nut consumption and risk of pancreatic cancer in women. Br J Cancer 109: 2911-2916, 2013.

9 Jenab M, Ferrari P, Slimani N, Norat T, Casagrande C, Overad $\mathrm{K}$, Olsen A, Stripp C, Tjonneland A, Boutron-Ruault MC, Clavel-Chapelon F, Kesse E, Nieters A, Bergmann M, Boeing H, Naska A, Trichopoulou A, Palli D, Krogh V, Celentano E,
Tumino R, Sacerdote C, Bueno-de-Mesquita HB, Ocke MC, Peeters PH, Engeset D, Quiros JR, Gonzalez CA, Martinez C, Chirlaque MD, Ardanaz E, Dorronsoro M, Wallstrom P, Palmqvist R, van GB, Bingham S, San Joaquin MA, Saracci R, Kaaks R and Riboli E: Association of nut and seed intake with colorectal cancer risk in the European Prospective Investigation into Cancer and Nutrition. Cancer Epidemiol Biomarkers Prev 13: 1595-1603, 2004.

10 Liu Y, Colditz GA, Cotterchio M, Boucher BA and Kreiger N: Adolescent dietary fiber, vegetable fat, vegetable protein, and nut intakes and breast cancer risk. Breast Cancer Res Treat 145: 461-470, 2014.

11 Wu L, Wang Z, Zhu J, Murad AL, Prokop LJ and Murad MH: Nut consumption and risk of cancer and type 2 diabetes: a systematic review and meta-analysis. Nutr Rev 73: 409-425, 2015.

12 Aune D, Keum N, Giovannucci E, Fadnes LT, Boffetta P, Greenwood DC, Tonstad S, Vatten LJ, Riboli E and Norat T: Nut consumption and risk of cardiovascular disease, total cancer, allcause and cause-specific mortality: a systematic review and dose-response meta-analysis of prospective studies. BMC Med 14: 207, 2016.

13 World Health Organization (WHO). World Cancer Report 2014. Lyon, International Agency for Research on Cancer, 2014.

14 Durko L and Malecka-Panas E: Lifestyle Modifications and Colorectal Cancer. Curr Colorectal Cancer Rep 10: 45-54, 2014.

15 Lee J, Shin A, Lee J, Park JW, Oh JH and Kim J: Abstract 1748: The relationship between nut consumption and risk of colorectal cancer. AACR 107th Annual Meeting 2016 April 16-20 New Orleans, LA, USA, 2016.

16 Aune D, Chan DSM, Lau R, Vieira R, Greenwood DC, Kampman E and Norat T: Dietary fibre, whole grains, and risk of colorectal cancer: systematic review and dose-response metaanalysis of prospective studies. Br Med J 343, 2011.

17 Murphy N, Norat T, Ferrari P, Jenab M, Bueno-de-Mesquita B, Skeie G, Dahm CC, Overvad K, Olsen A, Tjonneland A, ClavelChapelon F, Boutron-Ruault MC, Racine A, Kaaks R, Teucher B, Boeing H, Bergmann MM, Trichopoulou A, Trichopoulos D, Lagiou P, Palli D, Pala V, Panico S, Tumino R, Vineis P, Siersema P, van DF, Peeters PH, Hjartaker A, Engeset D, Gonzalez CA, Sanchez MJ, Dorronsoro M, Navarro C, Ardanaz E, Quiros JR, Sonestedt E, Ericson U, Nilsson L, Palmqvist R, Khaw KT, Wareham N, Key TJ, Crowe FL, Fedirko V, Wark PA, Chuang SC and Riboli E: Dietary fibre intake and risks of cancers of the colon and rectum in the European prospective investigation into cancer and nutrition (EPIC). PLoS One 7: e39361, 2012.

18 Schlörmann W, Birringer M, Böhm V, Lober K, Jahreis G, Lorkowski S, Müller AK, Schöne F and Glei M: Influence of roasting conditions on health-related compounds in different nuts. Food Chem 180: 77-85, 2015.

19 World Health Organization (WHO): Diet, Nutrition, and the Prevention of Chronic Diseases: Report of a WHO Study Group. WHO Technical Report Series No. 797. Geneva, Switzerland, 1990.

20 DGE, ÖGE, and SGE. D-A-CH; Referenzwerte für die Nährstoffzufuhr. Bonn, 2015.

21 Alasalvar C, Shahidi F and Cadwallader KR: Comparison of natural and roasted Turkish tombul hazelnut (Corylus avellana L.) volatiles and flavor by DHA/GC/MS and descriptive sensory analysis. J Agric Food Chem 51: 5067-5072, 2003. 
22 Saklar S, Katnas S and Ungan S: Determination of optimum hazelnut roasting conditions. Int J Food Sci Tech 36: 271-281, 2001. http://onlinelibrary.wiley.com/doi/10.1046/j.13652621.2001.00457.x/abstract

23 Schlörmann W, Lamberty J, Lorkowski S, Ludwig D, Mothes H, Saupe C and Glei M: Chemopreventive potential of in vitro fermented nuts in LT97 colon adenoma and primary epithelial colon cells. Mol Carcinog 56: 1461-1471, 2017.

24 Lux S, Scharlau D, Schlörmann W, Birringer M and Glei M: In vitro fermented nuts exhibit chemopreventive effects in HT29 colon cancer cells. Br J Nutr 108: 1177-1186, 2012.

25 Demir AD and Cronin K: The thermal kinetics of texture change and the analysis of texture variability for raw and roasted hazelnuts. Int J Food Sci Tech 39: 371-383, 2004.

26 Richter M, Jurek D, Wrba F, Kaserer K, Wurzer G, KarnerHanusch J and Marian B: Cells obtained from colorectal microadenomas mirror early premalignant growth patterns in vitro. Eur J Cancer 38: 1937-1945, 2002.

27 Klenow S, Pool-Zobel BL and Glei M: Influence of inorganic and organic iron compounds on parameters of cell growth and survival in human colon cells. Toxicol In Vitro 23: 400-407, 2009

28 Glei M, Schneider T and Schlörmann W: Comet assay: an essential tool in toxicological research. Arch Toxicol 90: 23152336, 2016.

29 Pfaffl MW, Horgan GW and Dempfle L: Relative expression software tool (REST) for group-wise comparison and statistical analysis of relative expression results in real-time PCR. Nucleic Acids Res 30: 36, 2002. https://www.ncbi.nlm.nih.gov/pubmed/ 11972351

30 Schlörmann W, Hiller B, Jahns F, Zoger R, Hennemeier I, Wilhelm A, Lindhauer MG and Glei M: Chemopreventive effects of in vitro digested and fermented bread in human colon cells. Eur J Nutr 51: 827-839, 2012.

31 Borowicki A, Stein K, Scharlau D and Glei M: Fermentation supernatants of wheat (Triticum aestivum L.) aleurone beneficially modulate cancer progression in human colon cells. J Agric Food Chem 58: 2001-2007, 2010.

$32 \mathrm{Su}$ ZY, Shu L, Khor TO, Lee JH, Fuentes F and Kong AN: A perspective on dietary phytochemicals and cancer chemoprevention: oxidative stress, nrf2, and epigenomics. Top Curr Chem 329: 133-162, 2013.

33 Bolling BW, McKay DL and Blumberg JB: The phytochemical composition and antioxidant actions of tree nuts. Asia Pac J Clin Nutr 19: 117-123, 2010

34 Pelvan E, Alasalvar C and Uzman S: Effects of roasting on the antioxidant status and phenolic profiles of commercial turkish hazelnut varieties (Corylus avellana L.). J Agric Food Chem 60: 1218-1223, 2012

35 Schlörmann W, Birringer M, Lochner A, Lorkowski S, Richter $\mathrm{I}$, Rohrer $\mathrm{C}$ and Glei $\mathrm{M}$ : In vitro fermentation of nuts results in the formation of butyrate and $\mathrm{c} 9, \mathrm{t} 11$ conjugated linoleic acid as chemopreventive metabolites. Eur J Nutr 55: 2063-2073, 2016 .

36 Ebert MN, Beyer-Sehlmeyer G, Liegibel UM, Kautenburger T, Becker TW and Pool-Zobel BL: Butyrate induces glutathione Stransferase in human colon cells and protects from genetic damage by 4-hydroxy-2-nonenal. Nutr Cancer 41: 156-164, 2001.

37 Jahns F, Wilhelm A, Jablonowski N, Mothes H, Greulich KO and Glei M: Butyrate modulates antioxidant enzyme expression in malignant and non-malignant human colon tissues. Mol Carcinog 54: 249-260, 2015.

38 Pool-Zobel BL, Selvaraju V, Sauer J, Kautenburger T, Kiefer J, Richter KK, Soom M and Wolfl S: Butyrate may enhance toxicological defence in primary, adenoma and tumor human colon cells by favourably modulating expression of glutathione S-transferases genes, an approach in nutrigenomics. Carcinogenesis 26: 1064-1076, 2005.

39 Scharlau D, Borowicki A, Habermann N, Hofmann T, Klenow S, Miene C, Munjal U, Stein K and Glei M: Mechanisms of primary cancer prevention by butyrate and other products formed during gut flora-mediated fermentation of dietary fibre. Mutat Res 682: 39-53, 2009.

40 Stein K, Borowicki A, Scharlau D and Glei M: Fermented wheat aleurone induces enzymes involved in detoxification of carcinogens and in antioxidative defence in human colon cells. Br J Nutr 104: 1101-1111, 2010.

41 Hinnebusch BF, Meng S, Wu JT, Archer SY and Hodin RA: The effects of short-chain fatty acids on human colon cancer cell phenotype are associated with histone hyperacetylation. J Nutr 132: 1012-1017, 2002

42 Yaku K, Enami Y, Kurajyo C, Matsui-Yuasa I, Konishi Y and Kojima-Yuasa A: The enhancement of phase 2 enzyme activities by sodium butyrate in normal intestinal epithelial cells is associated with Nrf2 and p53. Mol Cell Biochem 370: 7-14, 2012.

43 Miene C, Weise A and Glei M: Impact of polyphenol metabolites produced by colonic microbiota on expression of COX-2 and GSTT2 in human colon cells (LT97). Nutr Cancer 63: 653-662, 2011.

44 Schmitzer V, Slatnar A, Veberic R, Stampar F and Solar A: Roasting affects phenolic composition and antioxidative activity of hazelnuts (Corylus avellana L.). J Food Sci 76: S14-S19, 2011.

45 Borowicki A, Stein K, Scharlau D, Scheu K, Brenner-Weiss G, Obst U, Hollmann J, Lindhauer M, Wachter N and Glei M: Fermented wheat aleurone inhibits growth and induces apoptosis in human HT29 colon adenocarcinoma cells. Br J Nutr 103: 360369, 2010.

46 Pool-Zobel BLand Sauer J: Overview of experimental data on reduction of colorectal cancer risk by inulin-type fructans. J Nutr 137: 2580S-2584S, 2007.

47 Zeng $\mathrm{H}$, Claycombe $\mathrm{KJ}$ and Reindl KM: Butyrate and deoxycholic acid play common and distinct roles in HCT116 human colon cell proliferation. J Nutr Biochem 26: 1022-1028, 2015.

48 Kim YH, Park JW, Lee JY and Kwon TK: Sodium butyrate sensitizes TRAIL-mediated apoptosis by induction of transcription from the DR5 gene promoter through Sp1 sites in colon cancer cells. Carcinogenesis 25: 1813-1820, 2004.

49 Cao Y, Gao X, Zhang W, Zhang G, Nguyen AK, Liu X, Jimenez F, Cox CS Jr., Townsend CM Jr. and Ko TC: Dietary fiber enhances TGF-beta signaling and growth inhibition in the gut. Am J Physiol Gastrointest Liver Physiol 301: G156-G164, 2011.

50 Zhang Y, Zhou L, Bao YL, Wu Y, Yu CL, Huang YX, Sun Y, Zheng LH and Li YX: Butyrate induces cell apoptosis through activation of JNK MAP kinase pathway in human colon cancer RKO cells. Chem Biol Interact 185: 174-181, 2010 . 
51 Wang L, Luo HS and Xia H: Sodium butyrate induces human colon carcinoma HT-29 cell apoptosis through a mitochondrial pathway. J Int Med Res 37: 803-811, 2009.

52 Lazarova D, Lee A, Wong T, Marian B, Chiaro C, Rainey C and Bordonaro M: Modulation of Wnt Activity and Cell Physiology by Butyrate in LT97 Microadenoma Cells. J Cancer 5: 203-213, 2014.

53 Baskar AA, Ignacimuthu S, Paulraj GM and Al Numair KS: Chemopreventive potential of beta-Sitosterol in experimental colon cancer model-an in vitro and in vivo study. BMC Complem Altern M 10: 24, 2010.
54 Brown EM, Gill CI, McDougall GJ and Stewart D: Mechanisms underlying the anti-proliferative effects of berry components in in vitro models of colon cancer. Curr Pharm Biotechnol 13: 200209, 2012.

55 Falasca M, Casari I and Maffucci T: Cancer chemoprevention with nuts. J Natl Cancer Inst 106, 2014.

Received October 27, 2017

Revised November 10, 2017

Accepted November 13, 2017 